Zabitha Reka Vienanda $^{1}$; Moses Glorino Rumambo Pandin ${ }^{2}$

Airlangga University

Kampus B, Jl. Dharmawangsa Dalam, Airlangga, Kec. Gubeng, Kota Sby, Jawa Timur 60286 ํㅡㄹ zabitha.reka.vienanda-2020@fib.unair.ac.id and ${ }^{2}$ moses.glorino@fib.unair.ac.id

\title{
Book Review: \\ Jejak Peradaban Kerajaan Hindu Jawa 1042 - 1527 M : Sejarah Kejayaan Dan Keruntuhan Mataram Kuno Hingga Majapahit
}

(Civilization Traces of The Hindu Kingdom of Java 1042 - 1527 Ad: History of Ancient Mataram and The Cross of Mataram To Majapahit)

Prasetya Ramadhan; Publisher: Araska; City of publication: Bantul Yogyakarta; Publication Year: March 2021; Pages: 300 pages; ISBN: 978 - 623 - 7910 - 78 - 7

The purpose of is written to provide insight into the knowledge of the Kingdom of Hindu civilization which once reached its peak in Java, which is united with the story of the collapse of the Ancient Mataram Kingdom, which had overgrown and became the center of Hindu civilization and experienced setbacks due to feud by family members. These traces of the Javanese Hindu Kingdom's culture explain the history of the emergence, the conflicts that colored the account of the Kingdom - Hinduism in East Java, important events that occurred, legacies and ruins which were marked by civil war, and the emergence of a new religion, namely Islam. Therefore, writing it aims to provide knowledge about the history of the Hindu Kingdom civilization in Java, from its peak to the cause of its collapse.

The explanation is obvious and in a language that is easy to understand, so it is suitable for everyone who wants to know about the history of Hindu civilization in Java and also the history of the Ancient Mataram and Majapahit Kingdoms. All who read this do not have to research or use it as a reference for research but can be read as a knowledge enhancer. Because the language is light and easy to understand, it is also suitable for reading for teenagers who have history lessons at school or want to know about the history of the Hindu civilization in Java and its collapse. Therefore it can be a recommendation for all people and students who wish to learn about the history of Hindu civilization and the glory of the Ancient Mataram and Majapahit Kingdoms and their collapse.

This book also explains the relics of Hindu civilization that are still in use today, not only in the form of inscriptions and inheriting various literary and artistic works, but Hindu civilization also left legacies in the socio-political field. The government and political system of the Majapahit Kingdom were well organized and worked well. It can be seen from Pararaton and Nagarakretagama. This political concept was integrated with the idea of the universe, which gave birth to the cosmogenic view. Cosmoginos themselves are the foundation of the relationship between the human world and the universe. Not only that, the legacy of the Majapahit Empire that can be seen today is literature and art such as books and temples. This also explains about the Blambangan Kingdom, which is a Hindu kingdom at the easternmost tip of the island of Java. Thus, it is suitable for readers who want to know the relics of the Hindu civilization in Java, which are still in use and can be seen today. 
The book is necessary and essential to be reviewed or reviewed in order to have a deeper understanding of the contents of it. Not only that, but the reviewers also gain new knowledge and insights about Hindu civilization in Java. As with the view of cosmogenic, which is a legacy from the government and political system of the Majapahit Empire, which is still in use today and also a gift of literary and artistic works, it is thus seen indirectly that provides new knowledge or insights.

This book fulfills the needs of readers who want to know about the history of Hindu civilization in the Land of Java, not only that, it also discusses the peak of the glory of the Majapahit Kingdom, political journeys, the conflict that caused the collapse to the ruins of its glory in East Java. Those also discuss the triumph of the Singasari Kingdom, starting from debating the existence of two different versions of the two ancient references regarding the replacement of King Tumapel to threats from within the country. It can be seen that, has fulfilled the needs of readers who want to know about the triumphant history of Hindu civilization with the fairly complete and explicit book content.

It also discusses the legacy of the triumph of Hindu civilization in the Land of Java, especially the East, where these relics can be seen until now in the form of relics of literary and artistic works such as books and temples. Not only the legacy of literary and artistic works, Hindu civilization, especially the Majapahit Empire, which had a well-functioning political government system, also left the cosmogenic view, which was a combination of political concepts and the concept of the universe. It also discusses the Blambangan Kingdom, which is centered on the easternmost tip of the island of Java. According to Babad Tanah Jawa and Francois Valentyn, who were Dutch writers, in the 17th century, the Blambangan Kingdom was subordinate to Surabaya, but this is still in doubt.

That has an impact on the readers. By reading this, the readers will have new knowledge or insights about the triumphant history of Hindu civilization in Java, such as knowledge about the Blambangan Kingdom, which probably many people do not know about the existence of the Kingdom. Not only that, but readers may also learn about Mahapati, who is a cunning figure like the sengkuni character in the Mahabharata story, where Mahapati means a person who has big ambitions to become a ruler, but this Mahapati character is the name created by the author of Pararaton and does not exist or not. Found on any inscription. Thus it has an impact on the readers because there are many things that are explained that maybe most people don't know.

The influence of the book on readers is that they can know everything about the triumph of Hindu civilization in Java. As already explained, that discusses the peak of Hindu civilization to the collapse of Hindu civilization in Java with various conflicts that exist clearly. Readers can also find out about the emergence of the Hindu-style Kingdom and the competitions that occurred in the Kingdom, not only that, and readers can also find out more details about the figures in these Kingdoms, for example, such as Ken Arok, Jayakatwang, Patih Nambi, Mahapati, and Gajah Mada.

This includes evidence in the form of images of temples, statues, and inscriptions found such as, according to the Maribong Inscription, 1248 that Ranggaawuni, who has the title Sri Jayawisnuwarddhana Sang Mapanji Seminingrat Sri Salaka Kalana Kulama Dhumardana Kamaleksana, ruled in 1248-1268, not only that also includes information contained in two ancient references, namely Nagarakretagama and Pararaton. It book also includes a history originating from China which records that soldiers led by Raden Wijaya or from Majapahit had united with the Mongol army to fight against the Kadiri Kingdom ruled by King Jayakatwang, 
and after a month of conquest, Raden Wijaya killed 200 Mongol warriors who escorted him to Majapahit.

The evidence provided by that can convince readers because the evidence provided is in the form of images of statues, temples, and also inscriptions where the inscriptions are like documents written in the Kingdom era on rugged and durable materials. Those provides some evidence in almost all chapters, including in chapter 1, page 27, there is included a picture of a statue of Lord Vishnu riding an eagle made by order of Airlangga to honor Lord Vishnu, who is considered the 'God of War' who shelters Airlangga during difficult times until his re-conquest. Medang by him. This temple is located on the slopes of Mount Penanggungan, which was later called Belahan temple.

Chapter 1 discusses the emergence of the Hindu dynasty in East Java which began with the emergence of the Medang Kingdom led by Sri Isyana Wikramadharmottungadewa, who was none other than Mpu Sindok. After his death, because Empu Sindok did not have a son and was replaced by his daughter, he then married a Balinese aristocrat and had a son Makutawangsawardhana who continued the leadership of the Kingdom. Makutawangsawardhana has two children Mahendradatta and Dharmawangsa where Mahendradatta became the consort of King Udayana in Bali who later gave birth to Airlangga while Dharmawangsa became King Medang replacing Makutawangsawardhana. The Kingdom when led by Dharmawangsa became fast forward, Dharmawangsa also had big ambitions to control the sea trade routes controlled by the Sriwijaya Kingdom, so Dharmawangsa sent his soldiers to conquer the Sriwijaya Kingdom because he felt threatened that the King of Sriwijaya wanted to take revenge and take advantage of the weakness of the Medang Kingdom at the time it is marriage. With the wedding party, the Sriwijaya Kingdom attacked the Medang Kingdom, which was not ready to fight and in the end, the Medang Kingdom died. However, when Sriwijaya conquered Medang, it turned out that Airlangga and his wife managed to survive and hide in the forest where Airlangga was meditating to get an answer from Lord Vishnu for his revenge plan against Sriwijaya. Airlangga's victory over Sriwijaya spread throughout the Medang area, the people rejoiced and welcomed the news of the win. Here Airlangga made a statue of Lord Vishnu riding an eagle which was considered the god of war by Airlangga.

Chapter 2 of it discusses Arilangga, who was in the vortex of the Kingdom split conflict which began with Airlangga's efforts to improve the welfare of his people which continued with Airlangga's resignation to become a priest with the title Resi Adji Paduka Mpungku Sang Pinaka Catraning Bhuwana. Airlangga also divided his Kingdom for his two sons who were competing, namely Kadiri and Janggala. Continuing, discusses the glory of the Kingdom of Kediri which was able to defeat the influence of Sriwijaya's work. In this chapter on page 47, there is a picture of the Penataran temple which is a Hindu holy place that was built during the Kediri Kingdom era and was used until the time of the Majapahit Kingdom. Furthermore, in Chapter 3, discusses the conquest of Kediri by Tumapel and the birth of Singasari, which started from the origin of Ken Arok who was a famous thug who was able to conquer the Kediri Kingdom by joining the Brahmins who felt cornered because King Kertajaya thought that he was a god and wanted to be worshiped and because Ken Arok wished to conquer the Kediri Kingdom in the end Ken Arok started a war with the Kediri Kingdom which was called the Ganter War which was won by Ken Arok and the Singasari Kingdom was built. Continued until the union of the two breeds after the civil war. In this chapter, page 68, there is a picture of the statue of Anusapati made of andesite stones found in Kidal temple. 
In Chapter 4 of it discusses the sudden triumph of Singasari and Pralaya, namely the rise of Wishnuwardhana and Mahisa Campaka which made Singasari peaceful and conducive, there were no sibling quarrels that made Singasari in its heyday and which in the end collapsed because of Jayakatwang's coup plan. In this chapter on page 85 there is a picture of the statues of Joko Dolog and Amoghapsa which embodies the image of King Kertanegara. Furthermore, Chapter 5 discusses the return of Rajasawangsa to the peak of his power with the success of Sanggramawijaya taking advantage of the situation and attacking Jayakatwang who then expelled the Mongols, whose aim was to take revenge for what was done to Singasari and raise the rank of Wangsa Rajasa again, this chapter also includes a statue of a statue. On the chapter 6 , discusses the chaos of politics and power in the region where the appointment of Nambi as Patih Amangkubhumi caused chaos in the newly formed Majapahit Kingdom because many parties felt that it was better or more worthy to be a Patih Amangkubhumi. In Chapter 7, discusses the rebellious Dharmaputra and the emergence of Patih Gajah Mada where many people were secretly disappointed by Ra Kuti's appointment as King after getting rid of Jayanagara. Meanwhile they also continued to hunt down Jayanagara everywhere. Chapter 8 discusses the Dwitunggal Ratu Tribhuwana - Gayatri built Majapahit which was shaken after the death of Jayanagara who was stabbed by her own doctor. In that book, on page 181, there is a picture of the Gayatri statue found in his penendharmaan at Boyolangu temple, Tulungagung..

In Chapter 9, discusses the Majapahit Kingdom at the top of the archipelago, where Gajah Mada, who did not mess with his oath that was pronounced when he became a governor, carried out hard efforts from 1331 to 1364 to expand the power of the Majapahit Kingdom. Even until Patih Gaja Mada there was no politics, the expansion of Majapahit still continued. Chapter 10 discusses Bubat's tragedy and the mystery of Patih Gajah Mada's death, seeing the fallen ministers and kings, a group of women including Princess Dyah Pitaloka Citraresmi who felt very sad that in the end they decided to commit Belapati or commit suicide after her father and the entire Sundanese party died in battle, on page 247 includes a picture of a statue of Gajah Mada in front of the entrance to Petirtaan Madakaripura, where it is said that Gajah Mada left the Majapahit Kingdom and spent the rest of his life alone in the land of gifts from Prabu Hayamwuruk. Chapter 11 describes the civil war at the end of power, namely Paregreg which can be interpreted as a feud between Wikramawardhana, a king of the west, and the king of the East, namely Wirabhumi. Chapter 12 discusses the Sandyakala Majapahit and the elimination of Hindu civilization in the Land of Java, which began with the decline of the Majapahit Kingdom which was a sign that the loss of Hindu civilization in Java was replaced by the emergence of an Islamic-style kingdom which marked the start of Islamic civilization in Java. And in the last Chapter 13 discusses the remains of the Hindu civilization in Java such as temples, statues, inscriptions and not only that, there are relics in the form of the political system of the Majapahit Kingdom.

With the chapters in it the organization or structure of the discussion is good, everything is explained in order. It can be seen from the beginning of the discussion, namely Chapter 1 to the last discussion of Chapter 13 where the author lists from the beginning of the arrival of Hindu civilization in Java, the existence of the Medang Kingdom and the conflicts that existed until the conquest of the Kingdom to the last one, namely the Majapahit Kingdom, where the beginning of the emergence of the Kingdom Majapahit, its glory to the cause of its collapse and in the last 13 chapter of discusses the remains of Hindu civilization in Java, such as temples, inscription statues and the legacy of the political system of the Majapahit Kingdom. That is, it 
can be seen that discusses the chapters in an orderly structure so that the reader can understand them easily.

This book has complete information in easy to understand language and straightforward discussion. Thus, it is suitable for readers who want to know about Hindu civilization in Java with full details. That not only provides information but also includes evidence in the form of pictures of temples, statues and explanations based on inscriptions and two ancient references, namely Nagarakretagama and Pararaton, thus it can convince readers with the information described in that book.

The book has advantages, even though it is a history book but the language is very light and the discussion is clear and neatly structured, the author tells it in sequence starting from the beginning of the Medang Kingdom to the glory of the Majapahit Kingdom to its collapse which makes it easy for readers to understand the contents. It is also suitable for readers who want to know more thoroughly about Hindu civilization in Java, starting from its heyday to its collapse and with the inclusion of pictures of temples, statues of Hindu civilization, not only that, it provides an explanation based on the inscriptions that make it have complete information. With its advantages, it is suitable for readers who want to know the history of Hindu civilization in Java.

The weakness is that the cover is too simple, so it can be concluded that the cover is less attractive. The explanation of it is indeed easy to understand, but the discussion is not interesting for readers who just want to know, so it is a little boring. It discusses all the characters that exist in Hindu civilization but the many characters might make the reader a little confused so that it must be read over and over again.

With the weaknesses already mentioned, those need advice. These weaknesses can make it difficult to understand the contents of it easily. It would be nice if the weaknesses of a book that have been mentioned, such as a cover, can be made even more attractive, because those cover really influences readers to read it or not with an attractive cover, so many people will read it. Finally, a discussion that is less interesting and the number of characters described, it would be nice for the debate to be made so that the reader does not feel bored, it can be changed from the language style.

Zabitha Reka Vienanda and Moses Glorino Rumambo Pandin

\section{REFERENCE}

1. Ramadhan, P. (2021). Jejak Peradaban Kerajaan Hindu Jawa 1042 - 1527 M : Sejarah Kejayaan dan Keruntuhan Mataram Kuno Hingga Majapahit. Bantul, Yogyakarta: Araska.

\section{AUTHOR BIOGRAPHY}

The book entitled "Jejak Peradaban Kerajaan Hindu Jawa 1042 - 1527 M " written by a writer born in Probolinggo, East Java on April 18, 1988, namely Prasetya Ramadhan, S.Si., is a Head of Quality Assurance Department at PT. Indofood Asahi Sukses Beverages (Jember Plant). He also made several works, namely Panzerkorps - German Armored Division (1939-1941) (Nulisbuku Publisher, 2015), Industrial Microbiology; Microorganisms and Their Applications in Industry (Publisher Plantaxia [Imprint Graha Ilmu] 2015), Knowing Antioxidants - Antioxidant-Fighting 
Compounds (Publisher Graha Ilmu, 2015), and his latest book, Kill Hitler: Tracing the Trails of Hitler's Defeat and Death (Araska Publisher, 2019) . 